\title{
Impact of Fenthion on Ionic Regulation in the Blood of Freshwater Fish, Cyprinus carpio (Linn).
}

\author{
Leena Muralidharan \\ V.K.K.Menon collegeof com\& Sharad Dighe college of science, \\ Bhandup (east), Mumbai 42.,PG Dept of zoology, Mumbai University Maharastra,India.
}

\begin{abstract}
The blood of fresh water, edible fish, Cyprinus carpio was exposed to sub lethal concentration of fenthion for 24, 48, 72 and 96 h to evaluate alterations in the levels of minerals i.e., sodium, potassium, chloride, calcium and magnesium. The increased mineral sodium and potassium play an important role in neuromuscular excitability, acid-base balance and increased osmotic pressure of the fish. The decreased calcium is of great importance in blood coagulation, muscle contraction and nerve transmission of the fish. The increased magnesium participates in principal metabolic activities, in formation of bones and teeth. Reduction in Chloride ion contents may be due to blockage of chloride ion from gut into serum due to Fenthion stress.

Key Words: Cyprinus carpio; calcium, chloride; magnesium;, potassium; sodium
\end{abstract}

\section{Introduction}

Ionic regulation is the capacity of an organism to build up and maintain specific ionic gradients between body fluids and the cell fluids. The regulation of ionic composition of the body fluid is presumed to have adaptive significance for the organism (Burton 1973). Unfortunately, in today's world all the water resources such as lakes, ponds, rivers, sea etc. have become a common damp yard for domestic sewage, exposure for oils, industrial chemicals, pesticides, metals etc. Investigations carried out by [1]-to[22] have shown that pesticide impair osmoregulatory ability in many aquatic forms. The ionic regulation studies contribute valuable information to the role of ions in the blood chemistry of aquatic animals. Thus, the purpose of the present study was to know or study the influence of three sublethal doses of Fenthion for 60 days chronic exposure on blood electrolytes like $\mathrm{Na}^{+}, \mathrm{K}^{+}, \mathrm{Ca}^{++}, \mathrm{Mg}^{++}$and $\mathrm{Cl}^{-}$in the fish $\underline{\text { Cyprinus carpio. }}$.

\section{Materials And Methods:}

The fishes were brought to the laboratory and were acclimatized following the standard procedure. After acclimatization healthy looking fish were selected and divided into different groups of eight each and were exposed to $0.38,0.193$ and $0.096 \mathrm{mg} / \mathrm{l}$ Fenthion for a period of 60 days. A control group was also maintained in duplicate for comparison. All the other conditions such as feeding, changing of water, maintaining $\mathrm{pH}, 02$, temp. etc. were retained constant throughout the experimental period. The blood was removed at the end of 60 days test period from exposed and control fish by cutting their tail region. At first the trunk region was blotted with sterile .cloth and the blood was drawn into 2.5 c.c. disposable plastic syringe equipped with Z1 gauge short bevel needle. The collected fresh blood samples were centrifuged at a speed of 1000 R.P.M. for 10 minutes so as to separate blood corpuscles and serum. Clear serum thus obtained was used for further analysis . For determination of $\mathrm{Na}^{+}$and $\mathrm{K}^{+}$a flame photometer model was used as per method described by [23].The calcium content of blood was estimated by Clark-collip method which is modification of Kramer - Tisdals method as described by [23].The magnesium content of the blood was estimated by the method of [24] as described by [23] and[25].Estimation of chloride ion was done by following the method as described by [23].

\section{Results And Discussion:}

1; Fig. 4a.

The values of blood ions $\mathrm{Na}^{+}, \mathrm{K}^{+}, \mathrm{Ca}^{++}, \mathrm{Mg}^{+}$and $\mathrm{Cl}^{-}$in control and exposed fish are presented in table Sodium $\left(\mathrm{Na}^{+}\right)$:

Sodium is the major and chief cation of blood plasma. The important function of $\mathrm{Na}^{+}$in animal body appears to be in connection with osmoregulation and acid base balance besides catalytic effect on enzyme activity. Elevation in sodium ion level was observed in fish chronically exposed to 0.38 and $0.193 \mathrm{mg} / \mathrm{l}$ of Fenthion while at $0.096 \mathrm{mg} / \mathrm{l}$ Fenthion, not much difference in sodium ion levels was noted as compared to control ones. (Table .1; Fig. 4a.) Very few workers have experimented on ionic changes in blood of fresh water fish exposed to toxic substances. [3] observed elevated sodium level in buffer exposed to Endrin and suggested that this elevation is due to the loss of sodium ion from liver into the serum due to damage caused to liver. According to [4], serum osmolarity of the highest Endrin dosed trout, increased $4.4 \%$ over that of exercised control whereas osmolarity of exercised control increased only $2 \%$ above that of non exercised control and he 
Impact of Fenthion on Ionic Regulation in the Blood of Freshwater Fish, Cyprinus carpio (Linn).

further suggested that this elevation could be due to alternated cellular biopotentials. Kinter and Janicki 1971) noted elevation of sodium Anguilla prostrate exposed to DDT. According to [15],1[19],[20] ionic regulatory changes and acid base disturbance caused was due to alteration of gill function when rainbow trout $\underline{\text { Salmo }}$ gairdneri was exposed to zinc. [27], reported that ATPase enzyme is believed to constitute the pump responsible for the outward transport of $\mathrm{Na}^{+}$and inward movement of $\mathrm{K}^{+}$across the gill epithelium. According to [28] inhibition of ATPase and inhibition of oxygen uptake in the tissues may lead to disruption of osmoregulation in the fish.

Taking the support of these different views given by different workers, it may be suggested that in the present study, the elevation of sodium ion level in serum of exposed Cyprinus carpio could be due to oxygen debt, ATPase enzyme inhibition and histopathological damage to gill and liver tissues. Fig1-6,table5.1

\section{Potassium $\left(K^{+}\right)$:}

Here, in the present study, potassium content in the experimental blood was elevated as compared to control (Table No..1; Fig. 4a). Potassium is an important constituent of extra cellular fluid having a great influence on muscular activity. According to [12] potassium is the main intra cellular cation involved in physiological functions like acid base balance, osmotic pressure, nerve and muscle functions. It also helps in enzymatic transfer of phosphate from ATP to pyruvic acid and undoubtedly has a role in a number of basic cellular enzymatic functions. According to [29] exposure to sublethal concentrations of DDT and Endrin in fresh water fishes Anguilla vulgans and Mulgil cephalus impaired liver functions and this is evident from transfer of major cations from hepatic tissue to serum. [3] observed elevation in potassium content in buffer exposed to Endrin. [4] experimented on Endrin ( $0.01 \mathrm{ppb} 96 \mathrm{hr}$ ] dosed trout and reported that serum potassium level increased while potassium content in liver was lower than control and suggested that elevation of $\mathrm{K}^{+}$in serum was due to transfer of cations from injured hepatic tissue into serum.

Hyperkalemia was noted in Cyprinus carpio exposed to Fenthion in the present Study. According to [29], if there is no damage to gut epithelium, potassium which is more concentrated in plasma than in surrounding water would be expected to move from blood into gut resulting in lower potassium level. Since in the present work no such reduction in potassium level in the serum was observed, it can be interpreted that gut epithelium damage caused accumulation of potassium ion in blood resulting in hyperkalemia . Elevated level could also be due to interference of Fenthion in enzyme activity responsible for the active removal and excretion of potassium. Further, the damage caused, to gill and liver tissues observed might also be the reason in active expulsion of potassium ion. (fig1-6\&fig4a).

\section{Calcium $\left(\mathrm{Ca}^{++}\right)$:}

Ionised calcium has important functions in blood coagulation. It regulates water and inorganic ions through cell membrane and contributes in the maintenance of action potential in muscle and nerve cells. [2], reported hypercalcemic condition in Cyprinodont fish exposed to mercury. Although they suggested that liver damage was the most reasonable explanation but also at the same time elaborated that damaged gill epithelium causes increase in permeability, and the damage to intestinal mucosa causes free exchange of ions between gut content and submucosal bed, thus overall causing active expulsion of the electrolytes. In the present context hypercalcemia (table.1) observed in Cyprinus carpio supports the above suggestion (fig1-8). [14] related increase in calcium ion in Aldrin exposed fish with damage caused 'to liver and according to her increase was due to' leakage of ions to serum. [4] reported increase in calcium ion in goldfish exposed to Endrin chronically. According to [11] increased calcium ion in Channa puncfatus exposed to 2, 3-4 triamino azo benzene could be due to transfer of calcium from other tissues to serum.

Thus, hypercalcemia observed in present work could be attributed to leakage caused due to histopathological damage of intestine epithelium, liver and gill (fig1-8) Secondly, it can also be due to impairment in active expulsion of electrolytes.

\section{Magnesium $\left(\mathrm{Mg}^{++}\right)$:}

Magnesium ion activity extends to all major anabolic and catabolic processes involving the main metabolites, It activates large number of enzymes concerned in intermediatery metabolism. Hypermagnssia was observed in the present study in all the exposed fishes Table .1; Fig. 4a. [11] reported similar increase in magnesium ions in 2, 3-4 triamino azobenzene exposed Channa punctatus and suggested that it could be due to leakage of magnesium ions caused by tissue injury. [4] reported elevation in magnesium ions in serum of Endrin exposed goldfish. Excess of magnesium ion in serum can occur when absorption from gut exceeds excretion by kidneys. Hypermagnesia, can also be characterised from the depression of central nervous system, mentioned by Hawk et. al. (1965). According to [29] magnesium is needed for activation of alkaline phosphatase enzyme which if inhibited results in the liberation of free $\mathrm{Mg}^{+2}$ ions into the blood causing increase of magnesium in the blood. Alkaline phosphatase inhibition table 2 observed can be related with the, results obtained here. 
Hypermagnesia can also be due to impaired mechanism of excretion as reported by [12] who further stated that failure in active expulsion of ion results in accumulation of $\mathrm{Mg}^{+2}$ ion in serum blood.

In the present work hypermagnesia(table.1)can be related to damage caused to gill epithelium, Liver \& kidney tissues, thus causing leakage of $\mathrm{Mg}^{+2}$ ions into the blood circulatory system or it could also be due to inhibition in enzyme activity and impaired excretory mechanism(.fig4,5 \&table5.1)

\section{Chloride $(\mathrm{Cl})$ :}

Chloride ion is one of the major anions concerned in osmotic pressure regulation.Hypochloremia was observed in the present work (table.1)when Cyprinus carpio was exposed to different doses of Fenthion for 60 days.[4],[10],[30] observed similar decrease in chloride ion in different species of fish exposed to insecticides. [29] reported that the depletion in chloride ion could be due to the damage caused to gut epithelium which prevented the movement of chloride ions from gut into serum in cyprinodont fish exposed to Mercury.

In the present study, reduction in Chloride(Table.1\&fig4a) ion contents may be due to blockage of chloride ion from gut into serum due to Fenthion stress or it could also be due to leakage of $\mathrm{Cl}^{-}$from tissues to surrounding water due to insecticide stress.(fig6\&7)

\section{Conclusion:}

A comparison of control with chronically exposed Cyprinus carpio to Fenthion for period of 60 days exhibited elevation in sodium, potassium, calcium, magnesium \& depletion in chloride ion levels. This could be attributed to ATPase inhibition, damage caused to the important tissues and interference of Fenthion in transport of ions in blood.

\section{References:}

[1] Burton, R.F. (1973). The significance of ionic concentrations in the internal media of animals, Biol. Rev. 48, 195 - 231.

[2] Baldwin, E. (1949). An introduction to comparative biochemistry. 3rd Ed. Comp. Univ. Press, Lond. $164 \mathrm{pp}$.

[3] Eisler, R. and Edmounds, H. (1966). Effect of Endrin on blood and tissue chemistry of marine fish. Trans Am. Fish Soc. 95, 153 159.

[4] Grant. B.F. and Mehrle, P.M. (1970). Chronic Endrin poisoning in gold fish Carassinus auratus. J. Fish. Res. Board. Can. 27, 2225 $-2232$.

[5] Davis, P.W., Friedoff, J.M. and weedemeyer, G.A. (1972). Organochlorine insecticide and polychlorinated phenyl (PCB) inhibition of Na ATPase in rainbow trout. Bull. Env. Cont. Toxicol. 8, 59 - 72.

[6] Desaiah, D. Cutkamp, C.K. Yap, H.H. and Konch. R.B. (1972). Inhibition of oligomycin senstitive and insensitive magnessim adenosine triphoshate activity in fish by polychlorinated biphenyl. Biochem. Pharmacol. 21, 857 - 65.

[7] Cutkamp, C.K., Yah, H.H., Cheng, Y.Y. and Kouch, R.B. (1972). ATPase activity in fish tissue homogenate and inhibitory effects of DDT and related compound. Chem. Biol. Interaction. 3:4, 39 - 47.

[8] Kinter,W.B. \& Janicki, R.H. (1971). DDT disrupted osmoregulation event in the intestine of the eel Anguilla adapted to sea water. Science, $173,1146-48$

[9] Grant, B.F. and Mehrle, P.M. (1973). Endrin toxicosis in rainbow trout Salmo gairdneri. J.Fish Res. Board. Can. 30,31 - 40.

[10] Haux, G. and Larsson, A. (1979). Effects of DDT on blood plasma electrolytes in the Platichthys flasus in hypotonic brackish water. Ambio. 8, 171 - 173.

[11] Goel, K.A. and Garg_ V. (1980). 2-3-4 Triamino ozobenzene induced heamatological biochemical anomalies in fish C. puntatus. Bull. Env. ,Conl. Toxic. 25, $136-141$

[12] Larsson, A., Bangston, 13.L. and Haux, C. (1981). Disturbed ion balance in flounder Platichthys falsus exposed to sublethal levels of Cadmium. Aquatic Toxicol. Vol. 1, No.1, 19 - 36

[13] Weisbart, F.M. and Feinner,D (1974). Sublethal effect of DDT. on osmotic ionic and ionic regulation by gold fish Caraniuss auratus Can. J. Zool. 52(6), 739 - 44.

[14] Yagana Bano (1982). Effects of Aldrin on serum and liver constituents of fresh water cat fish Clarius batrachus. Proc. Ind. Acad. Sci. (Animal Sci). Vol. 91, No.1, Jan. 198227 - 32 pp.

[15] Spray Dauglas, J. and Chris, M.W. (1985). Can.J.Fish. Aquat. sci. 42(3) 1332 - 1341 (Abstract).

[16] Shastry, K.V. AND Dasgupta, A., 1991: Effect of nuvacron on the nutritive value of freshwater teleost fish, Channa punctatus. J. Environ. Biol., 12 (3): 243-248.

[17] Singh, N.N. AND Srivastava, A.K., 1998: Formothion induced biochemical changes inblood and tissues of freshwater catfish, Heteropneustes fossilis. Malys. J.Appl. Biol., 27 (1): 39-43.

[18] Singh, N.N., Srivastava, A.K. and Srivastava, A.K., 1993: Biochemical changes in thefreshwater Indian catfish, Heteropneustes fossilis following exposure to sublethal concentration of aldrin. J. Environ. Biol., 14 (1): 7-12.

[19] Mishra, D., Srivastaa, S., Srivastava, S.K. AND Srivastav,A. K., 2001: Plasma calcium and inorganic phosphate levels of a freshwater catfish, Heteropneustesfossilis in response to cypermethrin treatment. J. Ecophysiol. Occup. Hlth., 1:131-138.

[20] Tseng Y.C, Hwang P.P:2008: Some insights into energy metabolism for ionic regulation in fishes.C.Biochem.Physio.C.Toxicol.Pharmacol.,nov 148 (4)419-29.

[21] HWANG,P.P, LEE.T.H ANDLIN,L.Y 2011: Ionic regulation in fish gills recent progress inthecellularandmolecularmechanisms.Am.J.Phy.Regul.Integ.Comp.Physio.,July301(1)28-47.

[22] Abdul naveed.,Venkateshwarlu.P and Jannaiah.C. (2011):Impact of Triazophos on Ionic Regulation in the Blood of Freshwater Fish, Channa punctatus (Bloch) ,British Journal of Pharmacology and Toxicology 2(3): 113-118.

[23] Hawk, P.B., Oser, B.1.. and Summerson W.H. (1965). Hawk practical physiological chemistry 4th ed. ILL. Oser Mcgraw hill book comp. Inc., N.Y. Toranto, London.

[24] Neill. P.W. and Neely, R.A. (1956). As cited by Varley.H. (1963). 409 pp.

[25] Varley, H. (1953). Practical clinical Biochemistry. The White Frairs Press Ltd., London.

[26] Janicki, R.H. and Kinter, W.B. (1971). Nature, 233 - 184. 
Impact of Fenthion on Ionic Regulation in the Blood of Freshwater Fish, Cyprinus carpio (Linn).

[27] Adam, B.L., Zaugg, W.S. and Mc1ain.I,.R. (1973). Temperature effects on trout Salmo gairdneri as measured by gill sodium Potassium stimulated adenosine triphosphatase. Comp. Biochem. Physiol. 44 A. 1333 - 1379.

[28] Koundiyu, P.K. and Ramamoorthi.R. (1981). Tissue respiration of T.mossambica exposed to sublethal conc, of Sumithion and Sevinin ,Current Sci. No. 5, Vol. 50, p. 21

[29] Hilmy, A.H., Shabana, M.B. and Saiyed, M.M. (1982). Ionic regulation of the blood in the cyprinodont Aphanius under the effect of experimental Mercury pollution water. Soil. Pollution. 18, 467 - 473.

[30] Mishra, ,T.S. and Srivastava, A.K. (1983). Malathion induced haematological and biochemical change in the Indian cat fish' Heteropneustus fossils .Env. Res. 30, 393 - 98.

\begin{tabular}{|c|c|c|c|c|}
\hline $\begin{array}{l}\text { Ionic } \\
\text { Constituent }\end{array}$ & $\begin{array}{c}\text { Control } \\
\text { (Acetone + wafory }\end{array}$ & $0.096 \mathrm{mg} / 1$ & $0.193 \mathrm{mg} / \mathrm{l}$ & $0.38 \mathrm{mg} / \mathrm{l}$ \\
\hline $\begin{array}{l}\mathrm{Na}^{+} \\
\mathrm{meq} / \mathrm{l}\end{array}$ & $\begin{array}{l}135.6 \\
\pm 1.8\end{array}$ & $\begin{array}{l}136.2 \\
\pm 1.3 \\
0.44 \%\end{array}$ & $\begin{array}{l}137.4^{2} \\
\pm 2.0 \\
1.32 \%\end{array}$ & $\begin{array}{l}140.3 \\
\pm 3.3 \\
3.24 \%\end{array}$ \\
\hline $\begin{array}{l}\mathrm{K}^{+} \\
\text {meq } / 1\end{array}$ & $\begin{array}{l}0.86 \\
\pm 0.10\end{array}$ & $\begin{array}{l}0.90 \\
\pm 0.03 \\
4.65 \%\end{array}$ & $\begin{array}{l}0.96 \\
\pm 0.18 \\
11.62 \%\end{array}$ & $\begin{array}{l}1.0 \% \\
\pm 0.232 \\
16.27 \%\end{array}$ \\
\hline $\begin{array}{l}\mathrm{Ca}^{++} \\
\mathrm{meq} / 1\end{array}$ & $\begin{array}{l}5.4 * \\
\pm 0.32\end{array}$ & $\begin{array}{l}5.78 \\
\pm 0.24 \\
7.03 \%\end{array}$ & $\begin{array}{l}5.92 \\
\pm 0.21 \\
9.62 \%\end{array}$ & $\begin{array}{l}6.04^{*} \\
\pm 0.12 \\
11.85 \%\end{array}$ \\
\hline $\begin{array}{l}\mathrm{Mg}^{++} \\
\mathrm{meq} / 1\end{array}$ & $\begin{array}{l}3.55 \\
\pm 0.17\end{array}$ & $\begin{array}{l}3.69 \\
\pm 0.14 \\
3.94 \%\end{array}$ & $\begin{array}{l}3.98 \\
\pm 0.27 \\
12.11 \%\end{array}$ & $\begin{array}{l}4.12 \\
\pm 0.26 \\
16.05 \%\end{array}$ \\
\hline $\begin{array}{l}\mathrm{Cl}^{-} \\
\mathrm{meq} / 1\end{array}$ & $\begin{array}{l}117.0 \\
\pm 1.3\end{array}$ & $\begin{array}{l}113.0 \\
\pm 2.3 \\
-3.41 \%\end{array}$ & $\begin{array}{l}110.0^{* *} \\
\pm 1.4 \\
-5.98\end{array}$ & $\begin{array}{l}107.0 \\
\pm 0.9 \\
-8.54 \%\end{array}$ \\
\hline
\end{tabular}

\section{CHANGES IN IONIC CONSTITUENTS IN CYPRINUS CARPIO WHEN EXPOSED TO FENTHION CHRONICALLY FOR A PERIOD OF 60 DAYS.}

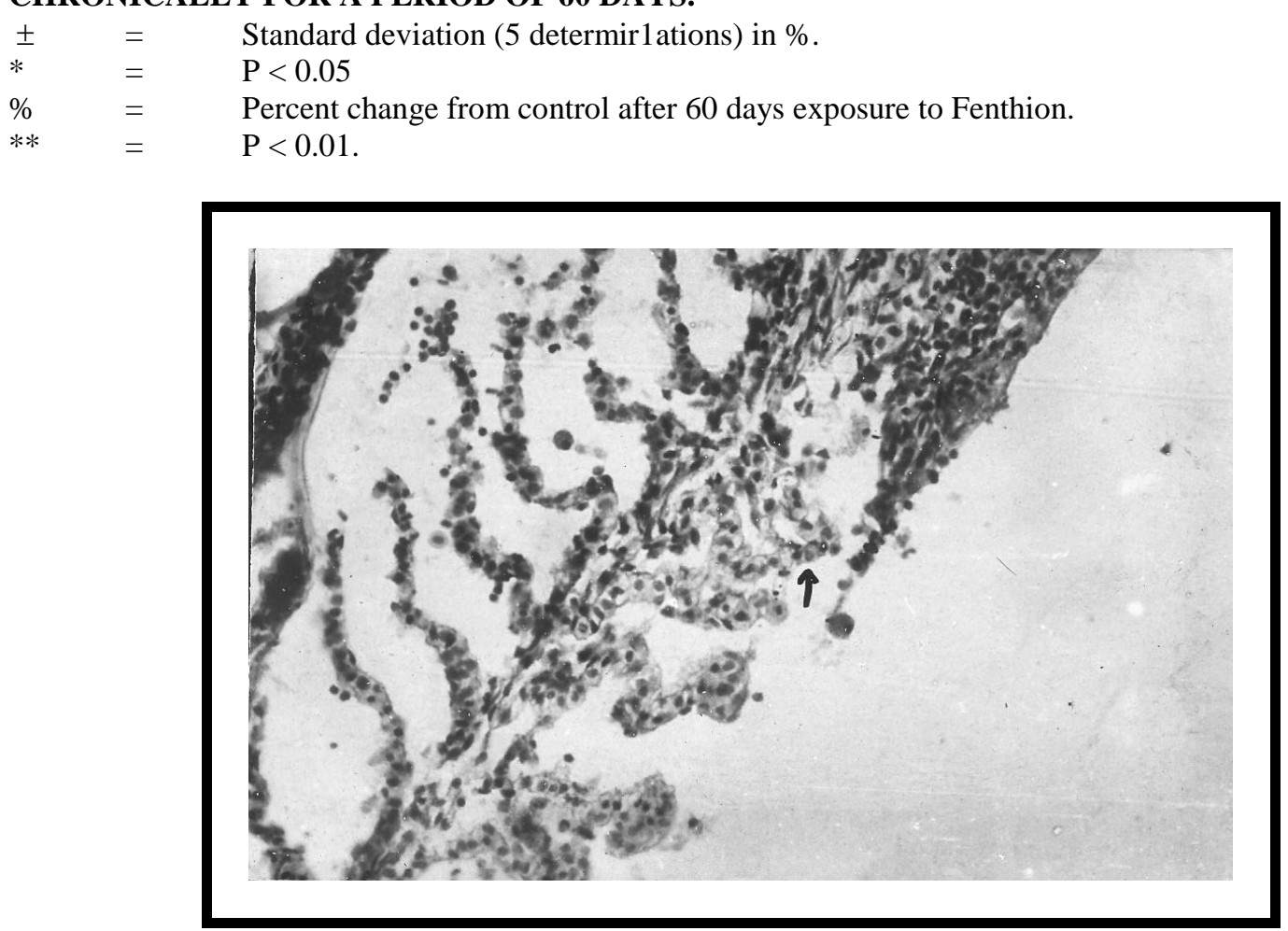

Fig1:Gill of fish exposed to $0.38 \mathrm{mg} / \mathrm{ml}$.Fenthion for 60 days exposure showing vacuolated, deformed and shortened secondary lamellae (arrow mark) 


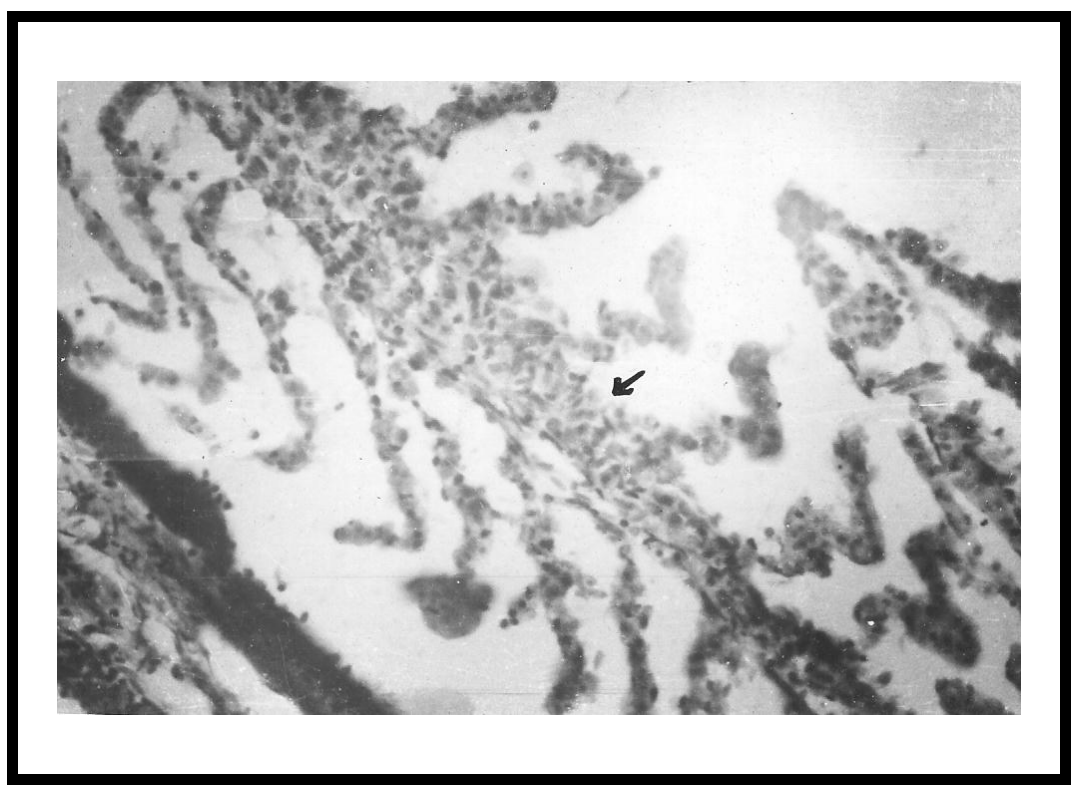

Fig2:Gills of fish exposed to0.193 mg/ml fenthion for 60 days showing ruptured secondary lamellae.

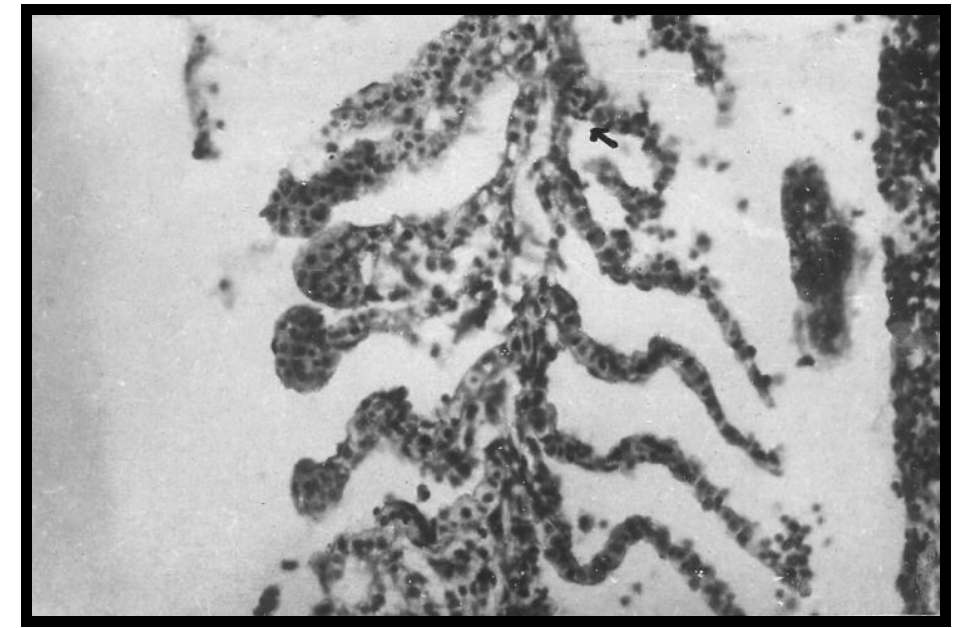

Fig 3:Gill of fish exposed to $0.96 \mathrm{mg} / \mathrm{ml}$ fenthion for 60 days showing disoriented epithelial cells and swollen chloride cells.

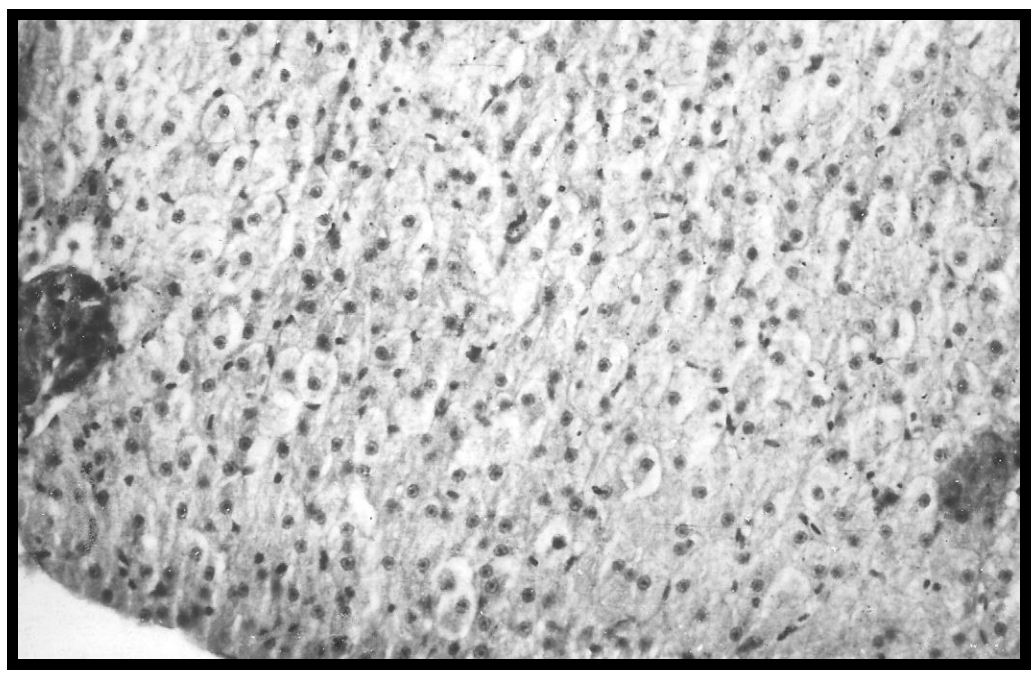

Fig 4:Liver of fish exposed to $0.096 \mathrm{mg} / \mathrm{ml}$ showing pycnosis and large number of necrotic regions. 
Impact of Fenthion on Ionic Regulation in the Blood of Freshwater Fish, Cyprinus carpio (Linn).

Fig5:Liver of fish exposed to $0.38 \mathrm{mg} / \mathrm{ml}$ fenthion showing vacuolated, cloudy swollen, disintegrated and extremely ruptured hepatic cells.
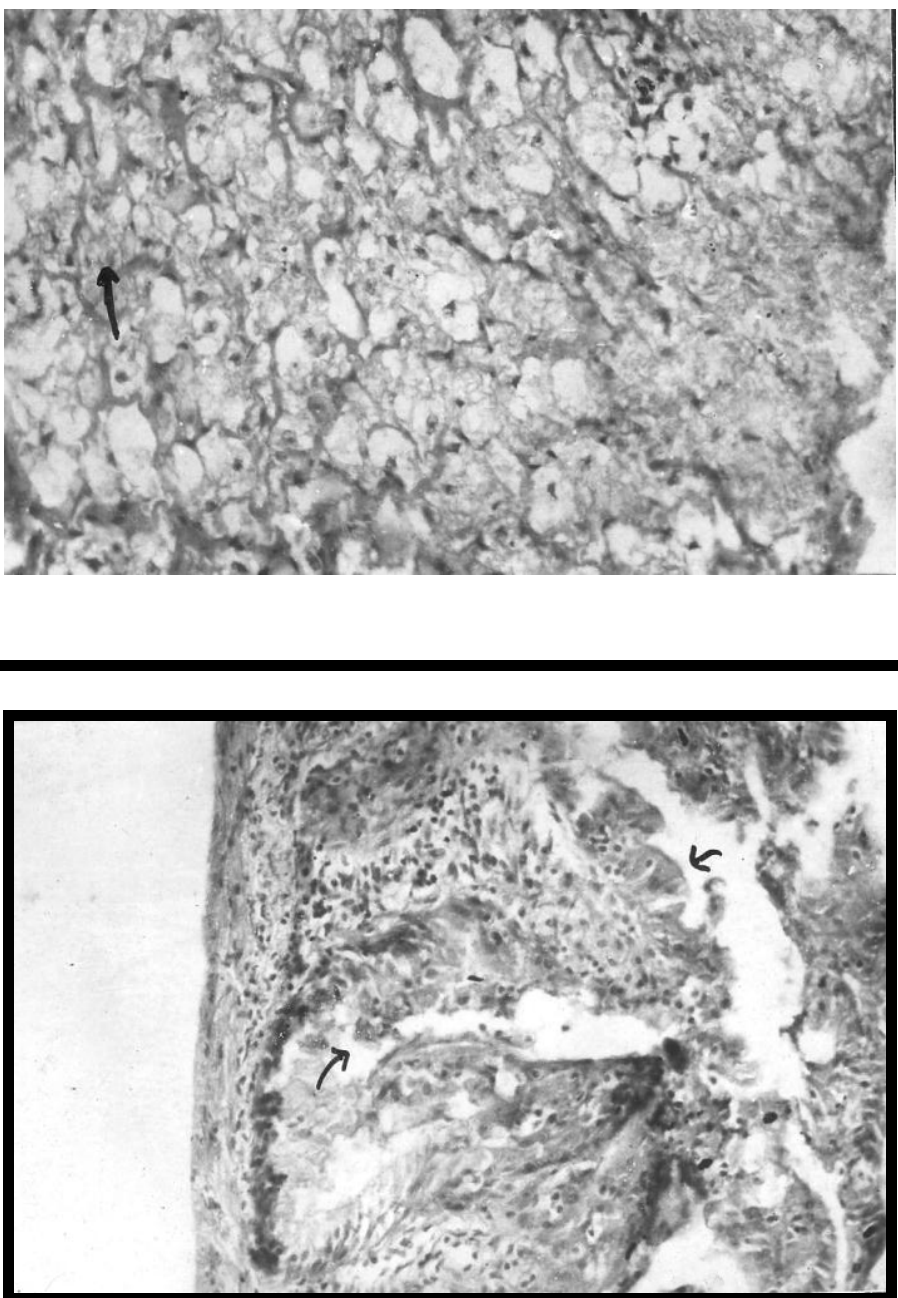

Fig6 Intestine of of fish exposed to $0.38 \mathrm{mg} / \mathrm{l}$ Fenthion showing epithelial cell lesion, shrunken and extremely damaged villi.

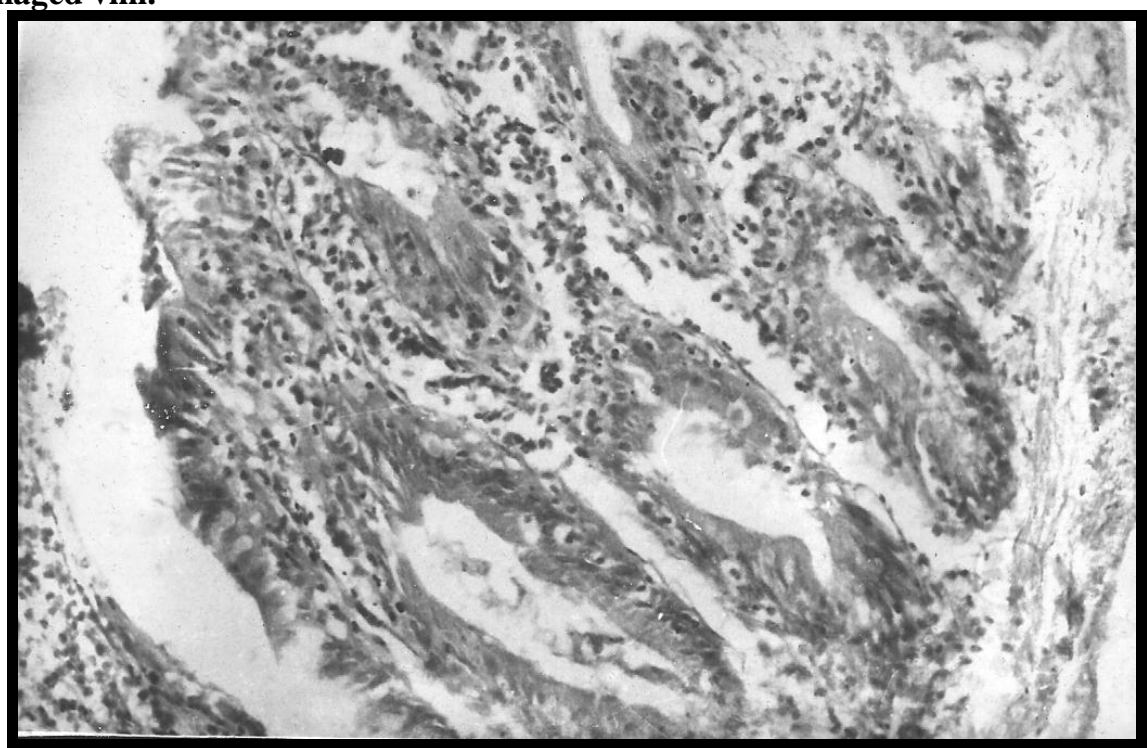

fig7:Intestine of fish exposed to $0.096 \mathrm{mg} / \mathrm{l}$ Fenthion showing ruptured epithelial cells increase in number of goblet cells. 


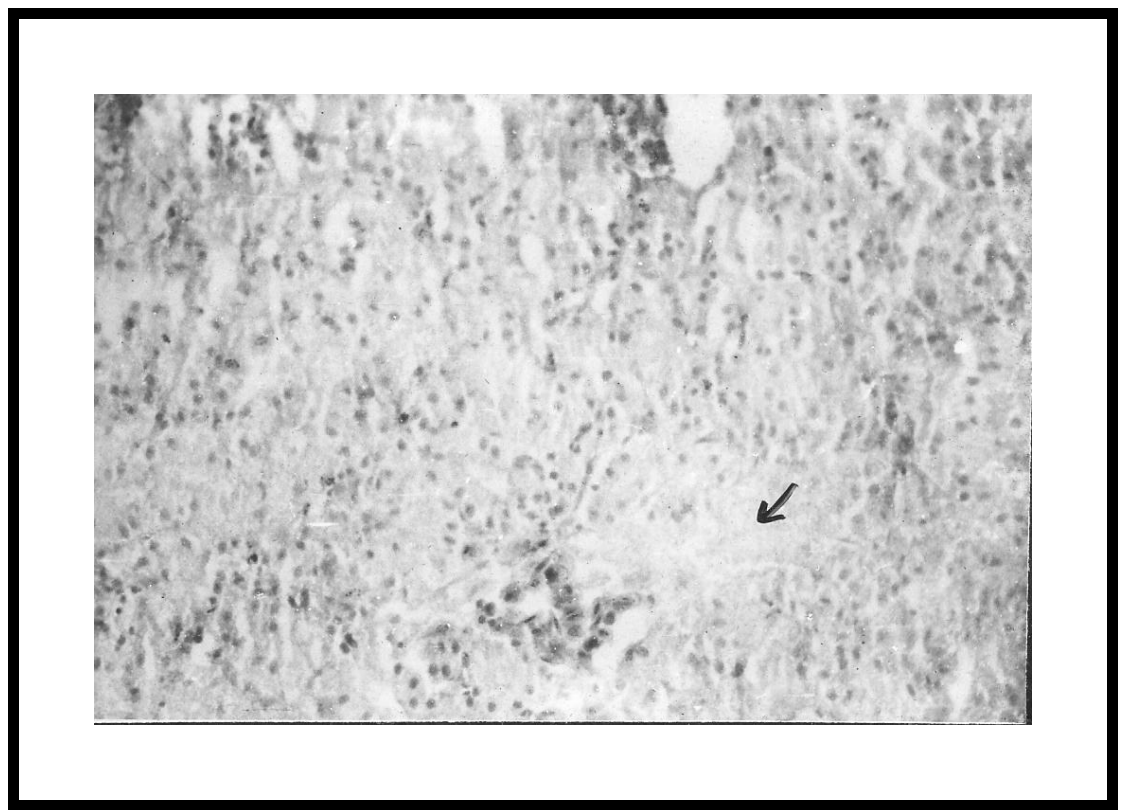

fig8: Kidney of fish exposed to0.193 $\mathrm{mg} / \mathrm{ml}$ fenthion showing extreme degeneration of renal cells.

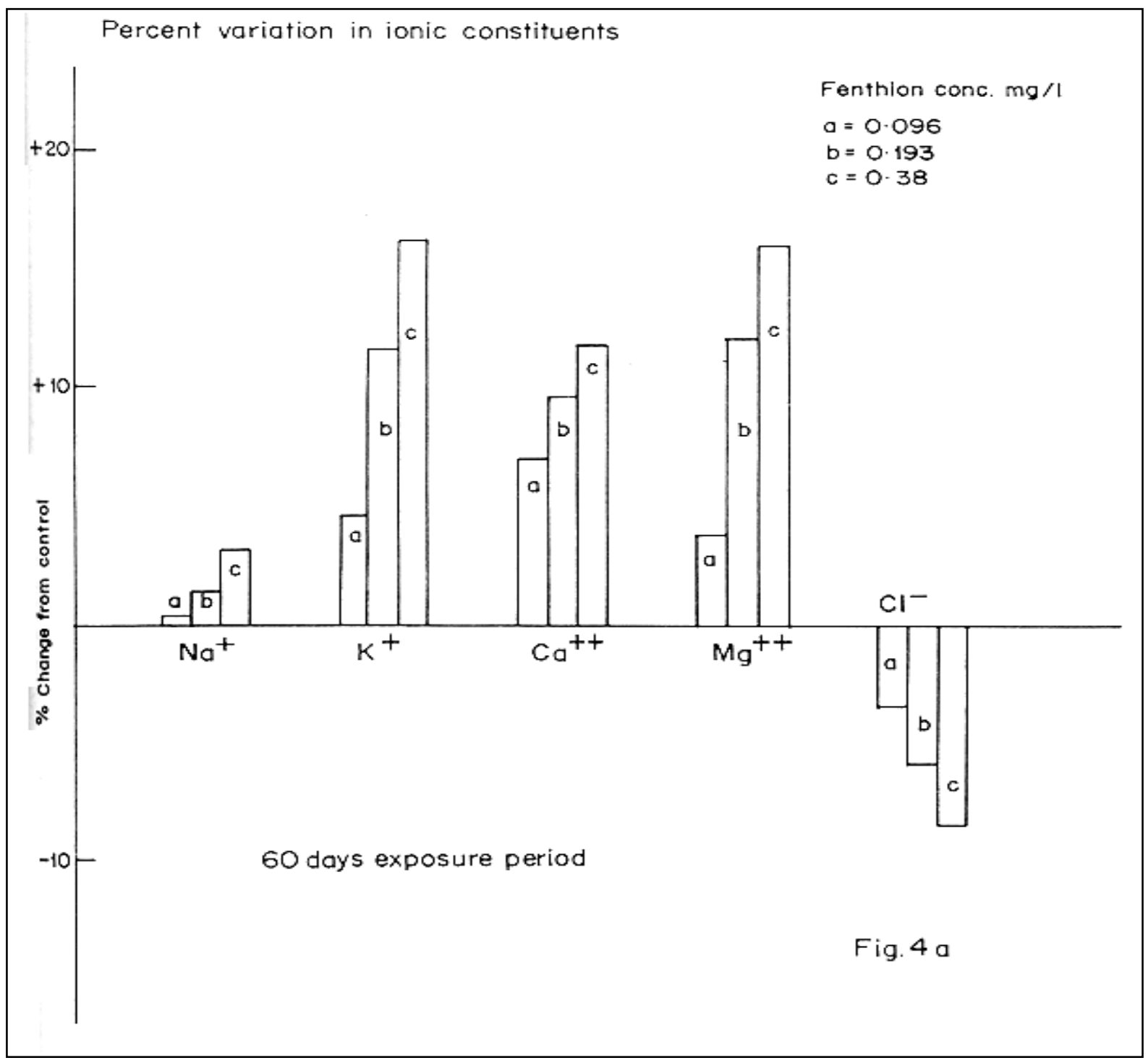




\begin{tabular}{|c|c|c|c|c|}
\hline $\begin{array}{l}\text { CHANGES IN ENZYME } \\
\text { CHRONIC EXPOSURE TO }\end{array}$ & $\begin{array}{l}\text { ACTIVITY IN } \\
\text { FENTHION. }\end{array}$ & MUSCLE & IISSUE AFTER & DAYS \\
\hline Enzyme & $\begin{array}{c}\text { Control } \\
\text { Accistonef wa }\end{array}$ & $0.096 \mathrm{mg} / \mathrm{l}$ & $0.193 \mathrm{mg} / \mathrm{l}$ & 0.38 \\
\hline $\begin{array}{l}\text { LDH } \\
\text { umole / hr/ mg protein }\end{array}$ & $\begin{array}{l}0.023 \\
\pm 0.0043\end{array}$ & $\begin{array}{l}0.020 \\
\pm 0.002 \\
-13.04 \%\end{array}$ & $\begin{array}{l}0.0098 \\
\pm 0.005 \\
-57.3 \%\end{array}$ & $\begin{array}{l}0.0076 \% \\
\pm 0.002 \\
-66.9 \%\end{array}$ \\
\hline $\begin{array}{l}\text { SDH } \\
\mu \mathrm{mole} / \mathrm{hr} . / \mathrm{mg} \text { jrotein }\end{array}$ & $\begin{array}{l}0.077 \\
\pm 0.004\end{array}$ & $\begin{array}{l}0.058 \\
\pm 0.001 \\
-24.6 \%\end{array}$ & $\begin{array}{l}0.041 \\
\pm 0.004 \\
-46.7 \%\end{array}$ & $\begin{array}{l}0.022^{*} \\
\pm 0.01 \\
-71.4 \%\end{array}$ \\
\hline $\begin{array}{l}\text { GOT } \\
\text { unit/hr/mg protein }\end{array}$ & $\begin{array}{l}79.34 \\
\pm 0.47\end{array}$ & $\begin{array}{l}60.0^{*} \\
\pm 0.325 \\
-24.3 \%\end{array}$ & $\begin{array}{l}50.3^{* * *} \\
\pm 0.042 \\
-36.6 \%\end{array}$ & $\begin{array}{l}34.4 \\
\pm 0.57 \\
-56.6 \%\end{array}$ \\
\hline $\begin{array}{l}\text { GPT } \\
\text { unit/hr/mg protein }\end{array}$ & $\begin{array}{l}48.63 \\
\pm 0.72\end{array}$ & $\begin{array}{l}40.88 \\
\pm 0.77 \\
-16.10 \%\end{array}$ & $\begin{array}{l}30.25 \\
\pm 0.68 * * * \\
-37.7 \%\end{array}$ & $\begin{array}{l}19.58 \\
\pm 0.43 \\
-59.73 \%\end{array}$ \\
\hline $\begin{array}{l}\text { AcP } \\
\text { ug } \mathrm{p} / \mathrm{hr} / \mathrm{mg} \text { protein }\end{array}$ & $\begin{array}{l}0.667 \\
\pm 0.011\end{array}$ & $\begin{array}{l}0.460 \\
\pm 0.013 \\
-31.0 \%\end{array}$ & $\begin{array}{l}0.379 \\
\pm 0.01 \\
-44.2 \%\end{array}$ & $\begin{array}{l}0.372 \\
\pm 0.012 \\
-43.6 \%\end{array}$ \\
\hline $\begin{array}{l}\text { AlP } \\
\mu \mathrm{g} \mathrm{p} / \mathrm{hr} / \mathrm{mg} \text { protein }\end{array}$ & $\begin{array}{l}0.661 \\
\pm 0.016\end{array}$ & $\begin{array}{l}0.521 \\
\pm 0.013 \\
-21.1 \%\end{array}$ & $\begin{array}{l}0.501 \\
\pm 0.099 \\
-24.2 \%\end{array}$ & $\begin{array}{l}0.497 * * \\
\pm 0.013 \\
-24.8 \%\end{array}$ \\
\hline $\begin{array}{l}\text { ATP } \\
\mu \mathrm{g} \mathrm{p} / \mathrm{hr} / \mathrm{mg} \text { protein }\end{array}$ & $\begin{array}{l}14.58 \\
\pm 1.2\end{array}$ & $\begin{array}{l}14.42 \\
\pm 0.9 \\
-1.09 \%\end{array}$ & $\begin{array}{l}13.86 \\
\pm 1.0 \\
-4.93 \%\end{array}$ & $\begin{array}{l}10.50 \\
\pm 1.3 \\
-27.9 \%\end{array}$ \\
\hline
\end{tabular}

